\title{
Overview of the developments in the domestic airline industry in South Africa since market deregulation
}

\author{
Authors: \\ Rose Luke ${ }^{1}$ \\ Jackie Walters ${ }^{1}$ \\ Affiliations: \\ ${ }^{1}$ Institute of Transport and \\ Logistics Studies (Africa), \\ University of Johannesburg, \\ South Africa \\ Correspondence to: \\ Rose Luke \\ Email: \\ rluke@uj.ac.za \\ Postal address: \\ PO Box 524, Auckland Park, \\ Johannesburg 2006, \\ South Africa \\ Dates: \\ Received: 13 Aug. 2013 \\ Accepted: 02 Oct. 2013 \\ Published: 18 Nov. 2013 \\ How to cite this article: \\ Luke, R. \& Walters, J., \\ 2013, 'Overview of the \\ developments in the \\ domestic airline industry in \\ South Africa since market \\ deregulation', Journal of \\ Transport and Supply Chain \\ Management 7(1), Art. \#117, \\ 11 pages. $\mathrm{http}: / / \mathrm{dx}$.doi. \\ org/10.4102/jtscm.v7i1.117

\section{Copyright:} \\ (C) 2013. The Authors. \\ Licensee: AOSIS \\ OpenJournals. This work \\ is licensed under the \\ Creative Commons \\ Attribution License.
}

Read online:
Deregulation or liberalisation of air transport has had major global impacts on the domestic air transport markets, with effects ranging from stimulation to changes in the structure and functioning of these markets. In South Africa, deregulation has had wide-reaching effects on the domestic market. The purpose of this article was to investigate the current domestic air transport market. A literature review was performed to examine the effects of deregulation in other domestic air transport markets around the world. This was followed by a review of the South African domestic air transport market prior to deregulation in order to determine the changes that were made following deregulation. The ten-year period immediately following deregulation was also examined; this period was characterised by relatively large numbers of market entries and exits. A database was obtained from the Airports Company South Africa; air traffic movements, passenger numbers and load factors were evaluated. The study showed that the market is still characterised by regular market entries and exits. Also that the entry of the low-cost carriers has stimulated the market, resulting in increased air traffic movements, higher passenger numbers, higher load factors in general and the opening of a secondary airport in Gauteng, Lanseria International. Deregulation and, more specifically, the entry of the low-cost carriers has resulted in structural changes in the market and more choice for passengers.

\section{Introduction}

Deregulation of the air transport market in any country tends to have far-reaching impacts on the structure of the market, the traffic flows, passenger numbers, market entries (and exits), the level of competition and fares. In most countries, one of the most significant impacts on the market has been the introduction and subsequent growth of the low-cost carriers, particularly in domestic or short-haul markets. This has led to growth in low-cost carriers' market shares of anything from $1 \%$ (in highly-protected markets) to $65 \%$ of the total domestic air transport market (Economist. com 2013).

In the South African market, the period immediately following deregulation led to a flurry of airline entries and exits. Following the entry of the first low-cost carrier in 2001, the structure of the market has changed significantly, with the low-cost carriers appearing to have the effect of stimulating the market and creating growth in passenger numbers, increasing load factors and air traffic movements. It also lead to the increased use of Lanseria airport as an alternative airport to Johannesburg's main airport, Oliver Reginald Tambo International Airport (ORTIA). The purpose of this article was to describe the high-level developments in the domestic air transport market in South Africa since deregulation and to particularly consider the impact of the entry of the low-cost carriers on the current market.

\section{Literature review}

Most air-transport markets have been regulated at some point in the past. Lyth (1997:155) stated that deregulation is most easily understood in relation to its opposite, regulation, and that regulation was, and for many places remains, the rule for civil aviation. He further stated that the origins of regulation of the air transport industry could be traced back to the earliest days of the industry. Although freedom of the air was canvassed briefly before the First World War, the Paris Convention of 1919, also known as the Convention Relating to the Regulation of Aerial Navigation, recognised the 'complete and exclusive national sovereignty over the air space above a nation's territory' (Lyth 1997:155), thus paving the way for early regulation of the industry.

Lyth (1997) asserted that aside from the concept of national sovereignty, air transport developed within a regulatory system based on common interest. Aside from the USA, flag carriers were state owned and heavily subsidised. Minimising competition between them implied that everyone was saved from further expenditure. The USA's market developed somewhat differently as they did 
not carry the burden of flag carriers. However, Lyth (1997) described the market as regulated competition and although there were a fair number of service providers, the Civil Aviation Board protected incumbents from new competition and price wars, thus creating an oligopolistic structure. The airline industry was therefore highly regulated around the world in its early years.

Airline deregulation is the process of removing the barriers for airlines to enter a particular market place, as well as removing price controls. In the USA, the purpose of the 'Airline Deregulation Act of 1978 is ... to remove the governmental control over fares, routes, and market entries from commercial aviation' (USLegal n.d.). Some of the goals were therefore to open the industry to competition and to open up opportunities for emerging airlines and secondary airports. In Europe, the:

... decision to create a single market in aviation formed part of the move to a single internal market across the whole range of economic activity, as embodied in the Single European Act (Butcher 2010).

The motivations for deregulation or liberalisation therefore differed from market to market, however the impacts were always significant.

In the USA, the Airline Deregulation Act of 1978 effected deregulation of the airline industry. Poole and Butler (1998:2) stated that 'what deregulation accomplished was to transform a static, cartelized aviation market into a dynamic, continually changing market'. They further stated that the impact of deregulation was felt in three main waves. In the first period, which was the ten years following deregulation, the main shift was the creation of hub-and-spoke systems by the major airlines. This implied schedule changes as well as reconfiguration of fleets to accommodate smaller aircraft on the spoke network. Airports were also affected as the hub-and-spoke system created congestion at some of the larger airports. In the second wave, and in response to the growing congestion at some of the major airports, opportunities developed for alternatives; one of the results was the creation of low-fare point-to-point services. The low fares led to expansion of the market and resulted in a number of new airlines trying to replicate the success of the pioneer low-cost carrier, Southwest Airlines. The latter's business model was, at the time, largely dependent on the use of underutilised airports, which also led to the development of the secondary airports. The third wave, according to Poole and Butler (1998), was the growth in the number of regional jets, a smaller type of jet airliner that was increasingly used to replace the turboprop, as it was more popular with travellers and more fuel-efficient. In essence, the deregulation of the air transport market in the USA led to the creation of the hub-and-spoke system, the creation and failure - 'since 1978, 160 airlines have come and gone' (Moris 2005) of new carriers, increased competition, discounted fares, growth in air travel and the creation of frequent flier programmes (avjobs.com n.d.)
In Europe, liberalisation was effected far later between 1988 and 1997. 'Three air transport liberalisation packages were implemented by EU countries, which created eventually a single aviation market for the EU community carriers by adding cabotage rights in 1997' (Oum et al. 2010). Smethers (2002) stated that there are four main effects of liberalisation, they are: industry structure, output, competition and fares. He elaborated by stating that the industry structure has changed. Although the number of carriers providing services is similar to pre-liberalisation, there has been considerable entry and exit from the market. There has also been growth in the membership of global alliances by the traditional airlines, as well as the rapid expansion of the low-cost carrier market. Output has increased, with more domestic and intraEU routes being served. Seats and Available Seat Kilometres (ASKs) have also increased significantly. There has been an increase in competition at route level, and fare levels have changed significantly. This is supported by an InterVISTAS report (2006) that shows that ASKs, number of passengers carried and operational Revenue per Kilometre (RPKs) has increased significantly since liberalisation. In addition, load factors have risen in general. The low-cost carrier business model relies on high capacity utilisation; so higher load factors are common amongst the low-cost carriers (De Boer \& Browning 2013; Najda 2003). Load factors have also increased for some of the legacy airlines, although not to the same extent as the low-cost carriers. Some legacy airlines have managed to achieve these increased load factors through measures such as channelling traffic through hub airports (Gorman 2009).

Deregulation in other parts of the world is more recent. In South East Asia, for example, open skies only started to take effect in 2009 (The Wall Street Journal 2013). In November 2012, Brazil joined the signatories of the Latin American Civil Aviation Commission (LACAC) Multilateral Open Skies Agreement (DiploNews 2012), although liberalisation started in 1993 (ICAO Brazil 2013). In 1992, deregulation of the air transport market in India led to an increase in passenger numbers as well as the number of carriers in the air transport market (Know India n.d.). Early indications from the emerging liberalised air-transport markets are that these will follow suit (Abouelaziz 2013; ICAO Brazil 2013; Wijaya 2010).

Deregulation has different effects on different markets. Levine (1997) stated that although studies support the prediction that a deregulated airline industry would be more efficient, there are a number of deviations from pure competition that can be observed in the airline industry. These include: mergers and consolidation; vertical integration; the development of huband-spoke systems; frequent flier programmes; new market casualties; and increasingly complex fare structures, amongst others.

Fu, Oum and Zhang (2010) considered the impact of airline liberalisation and determined that its economic effects included increased competition, reduced prices and traffic stimulation. It also impacted on production efficiency as 
well as employment in the industry. From an economic impact perspective, they also determined that air transport liberalisation had the effect of stimulating the economy as a whole. Further effects included: the emergence and development of hub-and-spoke systems and their related impact on reducing costs; the expansion and optimisation of air transport networks; and the emergence of low-cost carriers and their stimulation of traffic and increased levels of competition.

Donzelli (2010) asserted that the emergence of low-cost carriers shows that these support local development, including: creating jobs, stimulating tourism and increasing tax revenues. Graham and Dennis (2010) concluded in their study that low-cost airlines have had the effect of increasing tourist numbers. Inglada et al. (2006) reported that increasing competition has resulted in far greater technical and economic efficiency in the Asian airline market.

The effects of deregulation or liberalisation of air transport domestic markets globally can therefore be summarised as follows:

- Increased competition

- Stimulated traffic

- Increased efficiency

- Economic stimulation

- Entry of low-cost carriers

- High levels of market entry and exit

- Increased coverage

- Availability of low fares

- Increased use of secondary airports

- Increased passenger numbers

- Optimisation of carrier's networks, therefore change in traffic flows

- Greater availability of seats and ASKs

- Higher load factors, especially for low-cost carriers.

The rest of this article describes airline deregulation and the developments in the air transport sector in South Africa in three parts: the first section briefly describes the period prior to deregulation, the second section provides an overview of the period following deregulation between 1991 and 2000 and the last section describes the trends following the entry of the low-cost airlines in 2001 until 2012.

This article only describes the high-level market trends and provides a historical overview of some of the developments since deregulation. It is not possible to calculate things like yields and fare trends due to the unavailability of such data. It therefore does not attempt to analyse the effects of deregulation on the domestic air transport market in South Africa in detail, as insufficient financial data, particularly from the early years following deregulation, is available to conduct this type of analysis.

\section{Characteristics of the South African domestic air transport market prior to deregulation}

As a signatory (as part of the British Empire) to the Paris Convention of 1919 (Spacelaw n.d.), the South African air transport regulatory environment was based on the principle of air sovereignty (Lyth 1997). South African Airways (SAA), which is a government-owned airline that operates domestic, regional and international routes, was established on 01 February 1934 when the Government of the Union of South Africa took over the assets of Union Airways (Smith 1998).

As the flag carrier, SAA was protected from competition for over 40 years following the promulgation of the International Air Services Act, also known as the Air Services Act, Act No. 51 of 1949 (International Air Services 1949). At the time, SAA was the only service provider on all the main domestic routes. Airlines that wished to compete against SAA had to prove, amongst other things, that a need existed and that the incumbent airline was not delivering an adequate service. These requirements were outlined in Section 20 of the Act and were virtually impossible to meet in the presence of the domination of SAA. The result was that SAA had a complete monopoly on the high-density routes and the private sector airlines were relegated to feeder routes (International Air Services 1949).

Prior to the deregulation of the market, only four airlines were active in the domestic market:

- South African Airways (SAA) from 1934 (main routes and main airports)

- Comair from 1945 (secondary routes)

- Link Airways (later known as SA Airlink) from 1978 (secondary routes)

- Bop Air (later known as Sun Air) from 1979 (Smith 1998:241)

The first major study into the reorganisation of the domestic aviation industry began in 1979 when the government appointed a commission, the Margo Commission, to investigate civil aviation in South Africa. This resulted in a 'Report of the Commission of Inquiry into Civil Aviation in South Africa' (Margo 1984). The National Transport Policy Study (NTPS) followed this in 1985 (Behrens \& Wilkinson 2001), which focused on many of the same policy issues (Smith 1998). However, the NTPS study did not focus extensively on aviation matters as, at the time, the Department of Transport felt that it followed too soon after the Margo Commission of Enquiry.

In 1988, the Chief Directorate: Civil Aviation of the Department of Transport initiated another investigation into the status of the domestic air transport industry. The purpose was to revise the International Air Services Act of 1949 and to align it with the government's economic policy. The results of this study led to the publication of the Domestic Air Transport policy of 1990, which provided the basis for the deregulation of domestic air transport services in South Africa (Department of Transport 1990).

Following the acceptance of the policy, government then published the Air Services Licensing Act, Act No. 115 of 1990 (Air Services Licensing 1990), which officially deregulated the domestic market in 1991. 'Under the Act, which came into force in July 1991, the domestic market was fully deregulated 
by eliminating restrictions on market entry and exit, capacity, frequencies, and tariffs' (ICAO Secretariat 2008). At the time of deregulation of the airline industry, SAA had an estimated domestic market share of more than $90 \%$ of all scheduled passengers and $75 \%$ of these passengers travelled on the main routes, such as the Johannesburg, Cape Town and Durban routes (Smith 1998).

\section{Overview of the South African domestic air transport market following deregulation (1991-2000)}

In the first ten years following deregulation, the South African domestic air transport market was characterised by the entry, as well as exit, of many air transport service providers. This section provides an overview of the initial entrants into the deregulated market.

\section{South African Airways (SAA)}

SAA continued to provide services in the domestic market following deregulation; however it faced fierce competition from a new entrant, Flitestar, as well as from the expansion of services provided by an existing operator, Comair. A threetiered alliance was established late in 1993 between SAA and two new entrants, SA Express and SA Airlink, which enabled the airlines to operate under the same livery (Smith 1998) and provide an expanded service offering. These airlines fulfilled, amongst other things, feeder and distribution services for SAA that were serving the main commercial centres in the country with larger gauge aircraft.

\section{Flitestar}

Flitestar was the first privately owned airline to enter the domestic market following deregulation. It began operations during October 1991 with newly leased Airbus 320s. It initially focused on the Johannesburg-Cape Town route, with the Johannesburg-Durban-Port Elizabeth routes following shortly thereafter. The completion of the 'Golden Triangle' was achieved in January 1992 with its entry into the Durban-Cape Town routes (Smith 1998). In April 1994 the airline ceased operations after only 30 months of operation mainly due to high costs as a result of a weakening exchange rate and the fact the aircraft lease agreement was settled in US dollars. (Blake [1992] as quoted by Smith 1998:255).

\section{Comair}

Comair is the oldest privately owned domestic airline in South Africa and has been operating charter and low-density route services in South Africa since 1946. Following deregulation, it began operating on the main domestic routes on 03 August 1992 with a service between Johannesburg and Cape Town. The Johannesburg-Durban route followed in September 1993. In October 1996 the airline became a franchise holder of British Airways and became known as British Airways Comair (BA/Comair) (Comair Limited n.d.). The franchise agreement allowed it to use British Airways livery. It was listed on the Johannesburg Stock Exchange in 1998 (Imara 1998). In early 2000, British Airways Plc. acquired a minority shareholding in Comair (Africa News Service 2000).

\section{Phoenix Airways}

The airline began operations in December 1994 and focused on the Johannesburg, Durban and Cape Town routes. It operated four, used Boeing 727 aircraft, which proved to be very uneconomical when fuel costs increased significantly due to rand weakness and high maintenance costs were incurred. It also faced strong competition from Comair and Sun Air. The airline ceased business in 1995 (Smith 1998).

\section{SA Airlink (in alliance with SAA since 1993 and SA Express from 1994)}

SA Airlink began operations in 1992 following the collapse of an alliance between Magnum Airlines, Border Air and City Air, operating as Link Airways, due to financial problems (Leibowitz 1995 in Smith 1998). The airline still operates feeder routes to the main hubs in South Africa as well as regional air services (Airlink 2013).

\section{SA Express (SAX)}

SA Express (SAX) was established in late 1993 and began operations in 1994 (SA Express 2013a). Initially, SAA owned $20 \%$ of SAX, but later the entire shareholding was taken over by Transnet, which was then the holding company of SAA (Smith 1998). In 2007, this shareholding was transferred from Transnet to the Department of Public Enterprises (Department of Public Enterprises 2007). SAX still operates lower-density domestic routes (e.g., Bloemfontein, Kimberley, East London) and regional routes (SA Express 2013b).

\section{Sun Air}

Sun Air began operations in 1994 with DC9 aircraft and employed most of the former Flitestar staff. It operated on the main domestic routes in South Africa and expanded its services until 1999 when SAA announced that it had taken over the airline and subsequently closed it down (Flightglobal 2002; Smith 1998).

The first ten years following deregulation was characterised by a number of new entrants to the market; most of which failed in their original form. The only reconfigured or new airlines that were still operating at the end of this period were BA/Comair, SA Express and SA Airlink. It was therefore a turbulent time for the air traveller, as the market was characterised by significant instability. However, SAA remained dominant in the domestic market and strengthened this dominance through the alliance with SA Express and SA Airlink.

\section{Overview of the South African domestic air transport market since 2001}

Since 2001, the South African domestic air transport environment has been characterised by the entry of the low-cost carriers. The entry of the low-cost carriers led to a significant change in the functioning of the domestic market, primarily due to the growth that these carriers have affected. This is shown and discussed in the sections to follow. 
The first low-cost carrier to enter the market was kulula. com, when BA/Comair established South Africa's first low-cost airline. Kulula.com began operations in August 2001 (Flightsite 2013a). In 2006, kulula.com also began offering services from Lanseria, a secondary airport outside Johannesburg, to Cape Town and Durban (kulula.com 2006). The entry of kulula.com was followed soon after by the entry of 1time airline in 2004 (Planespotters 2013) and the launch of Mango (a fully-owned subsidiary of SAA) in October 2006 (Flightsite 2012a). 1time also offered services for a short time from Lanseria airport (05 March to 02 June 2012) (Lanseria International Airport 2012a, 2012b). 1Time suspended all services on 02 November 2012 (CH-aviation 2012). During March 2011, a new airline, Velvet Sky, began operations from Johannesburg to Cape Town. The Durban-based airline commenced operations between Johannesburg and Durban shortly thereafter, followed by flights to other destinations. It quickly ran into financial difficulties when it couldn't pay for technical services and fuel costs; it was finally liquidated during June 2012 (South Africa.To 2012). Mango's first flight was on 15 November 2006 (Gotravel24 2013). As was the case with the other low-cost carriers, it focused operations on the 'Golden Triangle' (Cape Town-Johannesburg-Durban) and later expanded its services to Lanseria Airport (in June 2011) with regular flights to Durban and Cape Town (Travelstart 2012). Table 1 below depicts the number of aircraft operated by the low-cost carriers, as well as the destinations served.

A characteristic of the low-cost airlines is that they concentrate mostly on the high-density domestic 'Golden Triangle'. Kulula.com also operates to Port Elizabeth and Mango to Bloemfontein. South African Airways has traditionally dominated the 'Golden Triangle', although recently it has lost some of its market share, largely due to the aggressive competition from the low-cost carriers and the potential to operate its aircraft more effectively in other markets. In 2010, it announced that it was withdrawing from the Durban-Cape Town route in favour of a code-share agreement with Mango (Orlek 2010), thereby relegating itself to only two of the legs of the 'Golden Triangle', that is, Johannesburg-Cape Town and Johannesburg-Durban.

\section{Research methodology}

To establish the primary trends in the air transport market in South Africa, the trends on the 'Golden Triangle' need to be determined, as these represent the majority of air traffic movements in South Africa (Airports Company South Africa [ACSA] 2013). In 2012, the Johannesburg-Cape Town route was the ninth busiest route in the world (The Economist online 2012). The section that follows outlines the high-level trends on the 'Golden Triangle' in South Africa since the entry of the low-cost airlines to the market.

The data used to calculate the figures is from the Airports Company South Africa (ACSA) database. ACSA (2013) collects passenger and air traffic movement (ATM) data from all arriving and departing carriers. This database is widely regarded as the most comprehensive of its kind in South Africa and contains detailed information of every airline's ATMs, passenger volumes and other associated information.

Data were used from January 1995 to December 2012. The database does not cover the period from deregulation in 1991 to 1994 and applicable data were therefore not available for the purposes of this analysis. It should also be noted that the data recorded between 1995 and 2001 need to be treated with caution, as ACSA changed from one database to another in 2001. In general, according to ACSA, the data prior to 2001 were not captured as accurately as after 2001. However, these data were included in this study, as they are the only available data on ATMs and provide the most accurate possible view of the high-level industry trends prior to the entry of the lowcost carriers into the domestic air transport market.

Due to confidentiality agreements between the individual airlines and ACSA, no individual airline's data are shown. The trends shown in the section below are therefore highlevel trends, where the individual airline information has been aggregated to the strategic level. Note also that the database does not contain any financial information on tickets sold, revenues and airline costs, as neither ACSA nor the South African government records this information.

\section{Research results}

\section{High-level trends on the 'Golden Triangle' in South Africa}

The purpose of this section is to outline the high-level trends in the domestic air transport market in South Africa and to determine whether deregulation and the entry of the lowcost carriers has had similar effects to the global trends, as outlined in the literature review.

Figure 1 is a depiction of the monthly passenger volumes on the 'Golden Triangle'. The lower of the two graphs represents the traditional carriers or full cost carriers (FCC) collated passenger volumes, whilst the upper graph depicts the total passenger movements. A Hodrick-Prescott filter (the dotted lines in the respective graphs, known as the hp-line)

TABLE 1: Low cost carrier domestic destinations.

\begin{tabular}{lllllll}
\hline Airline & Fleet Size & Cape Town & Durban & Port Elizabeth & $\begin{array}{l}\text { Johannesburg } \\
\text { (ORTIA) }\end{array}$ & $\begin{array}{l}\text { Johannesburg } \\
\text { (Lanseria) }\end{array}$ \\
\hline 1time (2004-2012) & 20 & $\mathrm{x}$ & $\mathrm{x}$ & $\mathrm{x}$ & $\mathrm{x}$ & $\mathrm{x}$ \\
kulula.com & 10 & $\mathrm{x}$ & $\mathrm{x}$ & $\mathrm{x}$ & $\mathrm{x}$ & $\mathrm{x}$ \\
Mango & 6 & $\mathrm{x}$ & $\mathrm{x}$ & - & $\mathrm{x}$ & $\mathrm{x}$ \\
Velvet Sky (2011-2012) & 4 & $\mathrm{x}$ & $\mathrm{x}$ & - & $\mathrm{x}$ & $\mathrm{x}$ \\
\hline
\end{tabular}

Sources: flightsite.com (2012; 2013); Gotravel24 (2013); kulula.com (2006); planespotter.com (2013)

ORTIA, Oliver Reginald Tambo International Airport 
was used to obtain a smoothed curve for the respective time series graphs. A characteristic of the filter is that it is more sensitive to fluctuations over the longer term than short-term fluctuations and is therefore used to show long-term trends in the data.

The space between the lines represents the passenger movements that can be attributed to the growth stimulated by the entry of the low-cost carriers. Although some of the growth may be attributed to normal population growth, or growth in the gross domestic product, the steep incline in the growth curve following the entrance of the low-cost carriers in 2001 suggests that the growth has mostly been stimulated by the entrance of the low-cost carriers. It is also evident from Figure 1 that the low-cost carriers have gained a significant share of the total market on the 'Golden Triangle' since their entry to the domestic air transport market, as the FCC hp-line has remained consistently lower than the total passenger movement graph. This is largely attributed to the growing South African economy, which has resulted in: higher levels of discretionary spending power; the aviation market growing with lower fares (stimulating demand); and passengers moving from traditional carriers to low-cost carriers.

The graph also shows that passenger volumes on the 'Golden Triangle' were largely stable (varying only between 900000 and 1.1 million passengers per month) until the middle of 2002, after which it shows a steep incline. Initially, the incline is equally strong for the traditional carriers and the total market, but the FFC line tapers off to reach a maximum of approximately 1.5 million passengers per month around September 2006. Thereafter it declines to an average of approximately $1.1 \mathrm{~m}$ passengers per month between 2008 to December 2012. The strong growth in passenger numbers is strongly associated with the entry of the low-cost carriers into the domestic market. The overall market shows continual growth to September 2007 (approximately $2.25 \mathrm{~m}$ passengers per month). Thereafter, passenger numbers appear to stabilise, or even decline, which is largely associated with the onset of the global recession at the time.

Although figures are not available for the period just after deregulation in 1991, Figure 1 generally shows that post deregulation, the market did not really grow significantly. Growth may have been expected with more airline choices and lower airfares becoming available as more carriers entered the market and levels of competition between carriers became higher. The graph shows that the real growth in domestic air transport really only began after the low-cost airlines entered the market.

Figure 2 illustrates the air traffic movements (ATMs) for the traditional or full-cost carriers (FCCs) and compares these to the total ATMs on the 'Golden Triangle'.

Figure 2 clearly indicates strong growth in air traffic movements following the entry of the low-cost carriers in 2001. Although the drop in the ATMs of the full-cost carriers in this initial period is relatively slow, the graph indicates

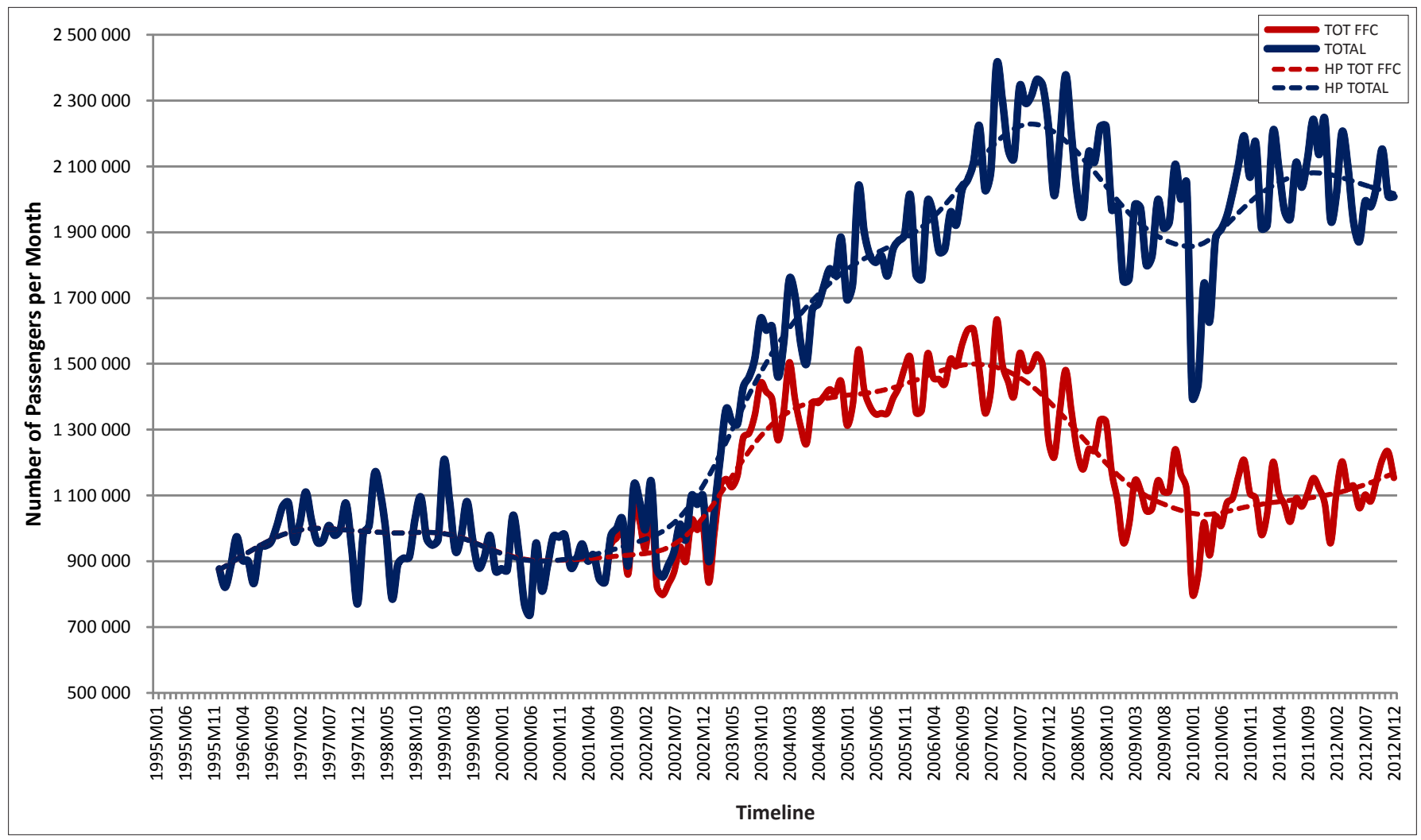

TOT FCC, Total full cost carrier passenger numbers; TOTAL, Total passenger numbers; HP TOT FCC, Hodrick-Prescott filter for total full cost carrier passenger numbers; HP TOTAL, Hodrick-Prescott filter for total passenger numbers

FIGURE 1: Passenger trends on the 'Golden Triangle' (total scheduled domestic arrivals and departures). 


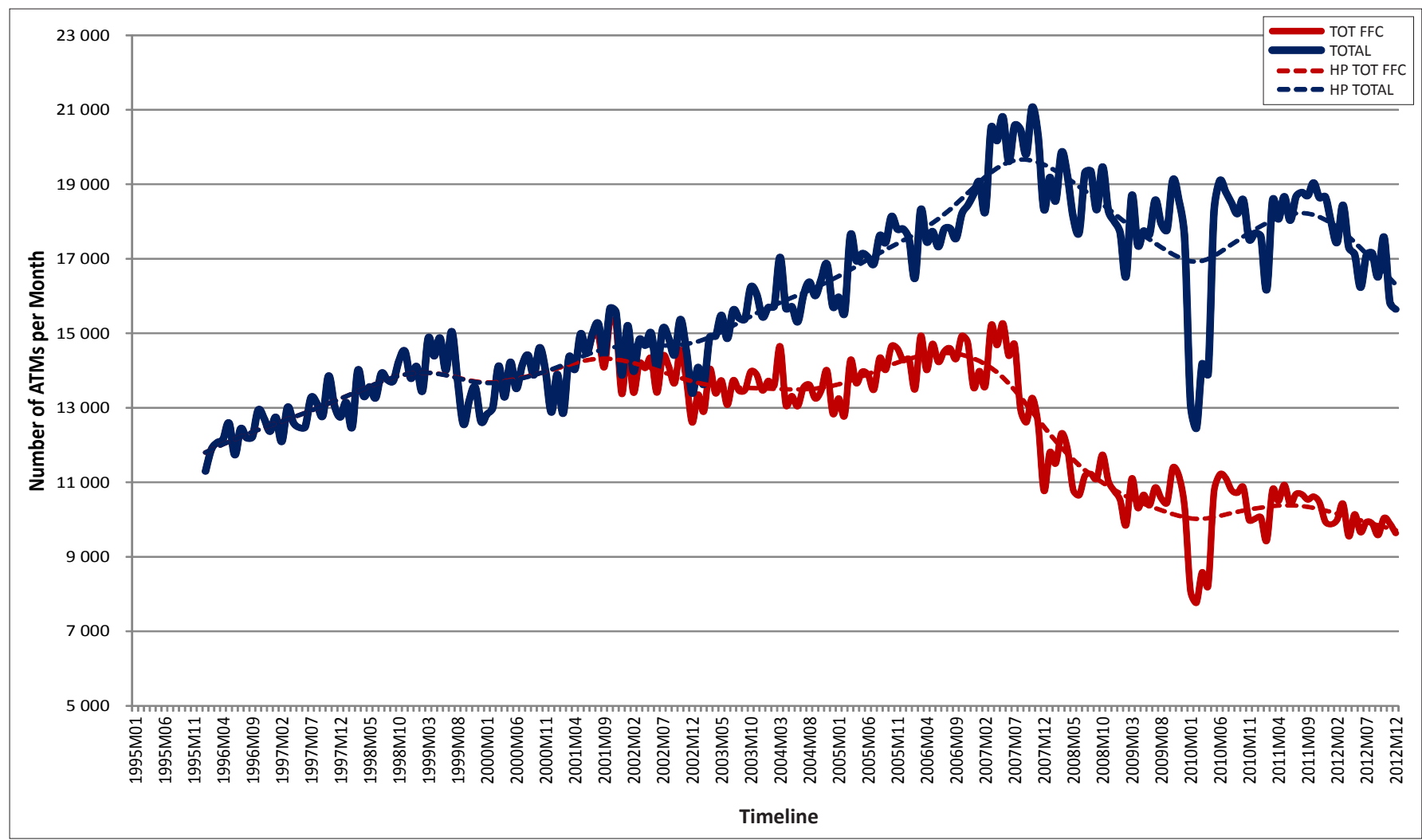

TOT FCC, Total full cost carrier air traffic movements; TOTAL, Total air traffic movements; HP Hodrick-Prescott filter for total full cost carrier air traffic movements; HP TOTAL, Hodrick-Prescott filter for total air traffic movements

FIGURE 2: Air Traffic movements on the 'Golden Triangle' (total scheduled domestic arrivals and departures).

that, over time, the full-cost carrier's ATMs have reduced significantly due to competition from the low-cost carriers. It should be noted that, prior to deregulation, SAA was the only role player in the market, giving a $\mathrm{CR}_{1}{ }^{1}$ index of $100 \%$. Following deregulation, the $\mathrm{CR}_{4}$ index has remained over $90 \%$, regardless of the number of market entries and exits, indicating a market that is not highly competitive. Although this does not allow for appropriate measurement of competition effects, Figure 2 clearly indicates that the entrance of the low-cost carriers have had a significant effect on the full service airlines' ATMs, where these have declined in real terms, despite the clear growth in the total number of ATMs over the period under review.

Figure 3 illustrates the differences between the full-cost and low-cost carriers' load factors.

During the initial period of low-cost carrier entry to the market, the low-cost carriers' load factors were very similar to those of the full-cost carriers. However, Figure 3 clearly shows how these load factors soon began to diverge (at the end of 2002). Between 2002 and 2012, the low-cost carriers'

1.Market concentration, as measured in terms of concentration ratios. CR1 shows the market share of the top company in the market. Where CR1 is $100 \%$ this indicates a pure monopoly. $\mathrm{CR}_{4}$ measures the market share of the top four role players in the market. Where this is highly concentrated, for example $80 \%-100 \%$, this indicates oligopolistic to monopolistic market conditions. The $\mathrm{CR}_{4}$ ratio was used rather than the Herfindahl-Hirschman Index (HHI), primarily because the exact market shares the Herfindahl-Hirschman Index ( $\mathrm{HHI}$ ), primarily because the exact market share of the various airline companies are unknown. The reason for this is firstly that the market shares of individual airlines cannot be disclosed due to the agreement between the airlines and ACSA, as described in the research methodology. The publically available information for Mango and SAA is reported together as Mango is a subsidiary of SAA. Similarly, kulula's and British Airways Comair's results are reported together. load factors were consistently higher than those of the fullcost carriers. As shown in the literature review, higher load factors are typical of the low-cost carriers. The graph also clearly indicates that the full cost carriers' load factors have also increased; this is most likely in response to increasing competition from the low-cost carriers and the associated need to become more cost efficient.

Between late 2003 and the end of 2010 the low-cost carriers generally reflected load factors in excess of $80 \%$, which only dropped below $80 \%$ towards the beginning of 2011 . It is likely that this can be ascribed to difficult economic times in South Africa, following the 2008 and 2009 worldwide recession, as well as excess capacity in the market, particularly with the aggressive growth strategy of the erstwhile 1time airline.

Figure 4 illustrates the changes in the low-cost carriers' market shares since kulula.com first entered the market in 2001.

The market share increases of the low-cost carriers on the 'Golden Triangle' are depicted by the lower line and measured on the right axis of the figure. Movements along this line are clearly attributable to the entry or exit of the lowcost carriers. Figure 4 clearly indicates that the LCCs market share approached almost $50 \%$ of the domestic air transport market on the 'Golden Triangle' at the beginning of 2012. Thereafter, the LCC market share declined to approximately $40 \%$ towards the end of 2012. This decline is largely attributable the more aggressive marketing on the part of 
the legacy carriers, as well as the demise of two low-cost carriers (Velvet Sky and 1time) in the same year. This could also be indicative of overcapacity in the market. Indications from the domestic airlines are that the low-cost carrier market share should settle at approximately $45 \%-50 \%$. It is widely expected that at least one new LCC entrant will enter

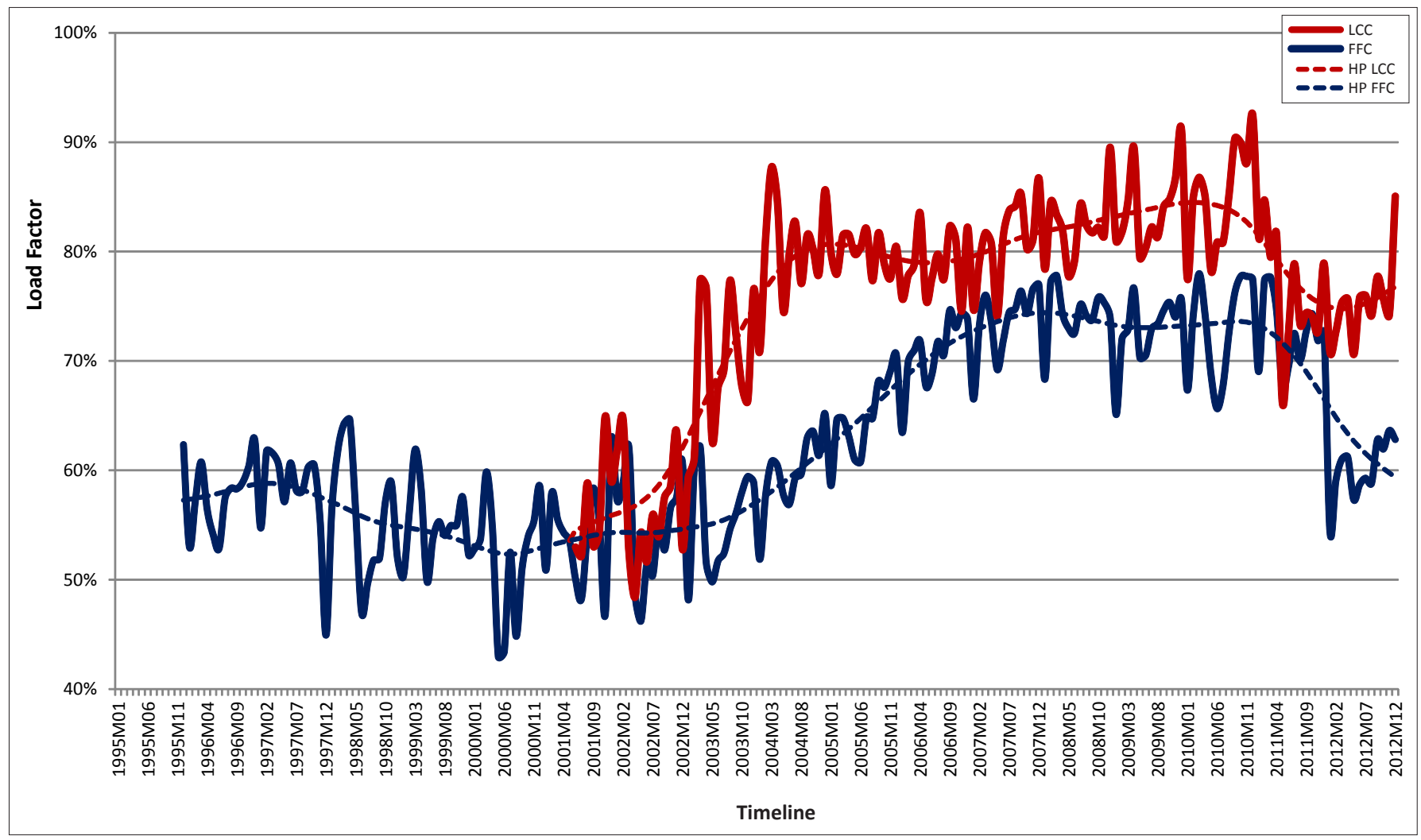

FCC, Full cost carrier load factors; LCC: Low cost carrier load factors; HP FCC, Hodrick-Prescott filter for full cost carrier load factors; HP LCC, Hodrick-Prescott filter for low cost carrier load factors FIGURE 3: Load factors on the 'Golden Triangle' (total scheduled domestic arrivals and departures).

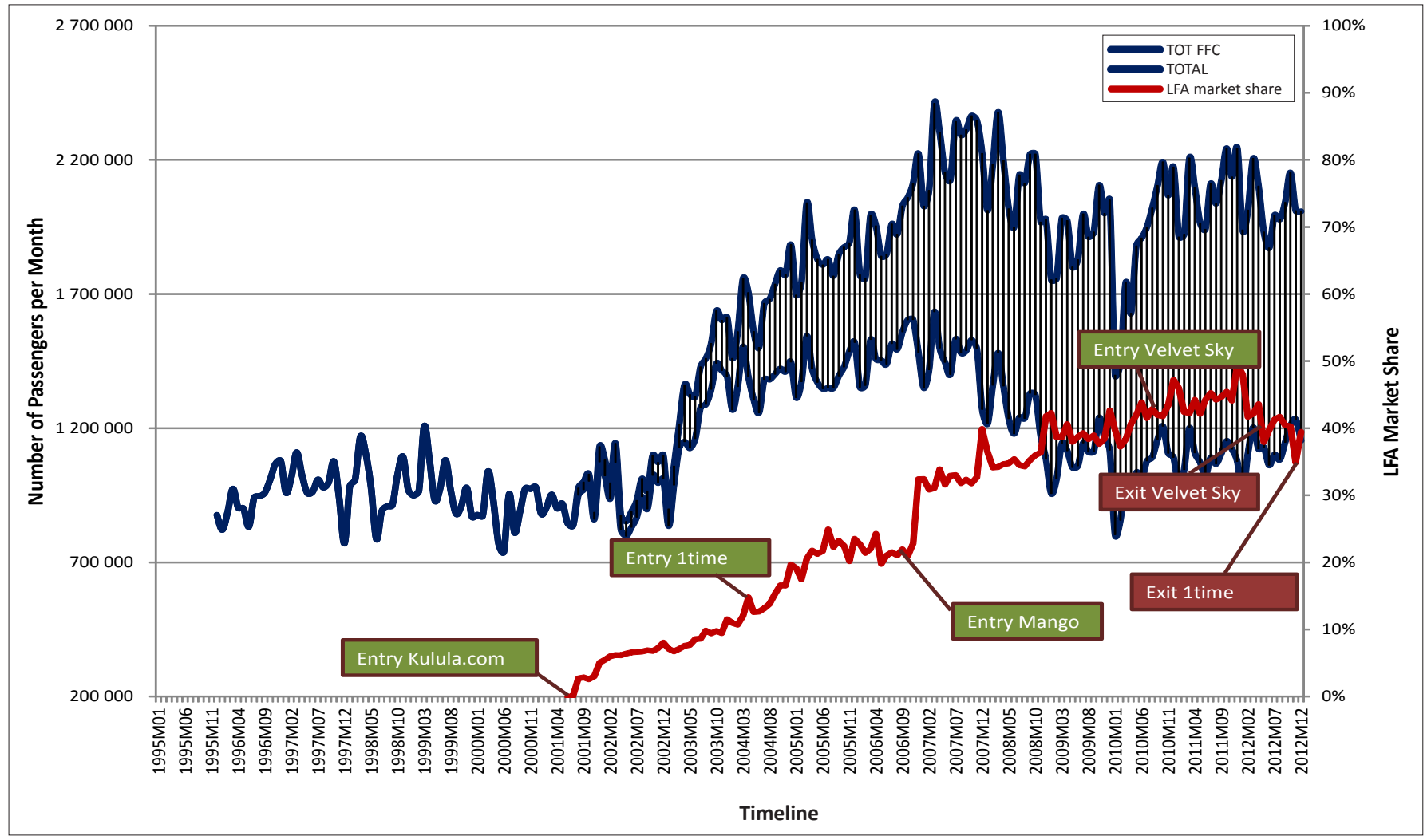

TOT FCC, Total full cost carrier monthly passenger numbers and market share; TOTAL, Total passenger numbers and market share; LFA market share, Low fare airlines market share FIGURE 4: Passenger trends on the 'Golden Triangle', including Low-Cost Carriers market share growth (total scheduled domestic arrivals and departures). 
the market in the near future (last quarter of 2013), thereby restoring the LCC market share to the levels achieved prior the exit of 1 time. Achieving an average market share of $45 \%$ $50 \%$ of the domestic market (Golden Triangle routes) would imply that the low-cost carriers' performance is amongst the highest in the world, where comparable countries are Brazil and Australia (40\%-49\%). Britain has an LCC share of approximately $50 \%$ and India $54 \%$. This is compared to countries with exceptionally high LCC market shares, such as the Philippines (65\%), and countries with very low LCC uptake, such as Russia (5\%), Japan (4\%) and China (1\%). The USA has an LCC market share of 30\%-39\% (Economist.com 2013).

One of the key features of the low-cost carrier business model has frequently been the use of underutilised secondary airports. This has not been a major feature of the domestic air transport market in South Africa, mainly due to the lack of availability of such airport infrastructure in the country. The use and success of Johannesburg's secondary airport, Lanseria, by two low-cost airlines has shown that this market has considerable scope for the use of alternative airports in the country and is aligned with global trends, described earlier in this article. Other cities on the 'Golden Triangle' do not have alternative airports that can be used by the low-cost airlines at present. Figure 5 depicts the growth of Lanseria
Airport, to the west of Johannesburg, as an alternative airport for the region.

The two low-cost carriers that currently operate from Lanseria airport - kulula.com and Mango - began operations in 2006 and 2011 respectively. Passenger volumes were initially low, but started to gain momentum from 2007 with current volumes at around 150000 passengers per month. The graph clearly shows strong growth in the secondary airport's passenger support, which indicates the scope for the use of such airports on dense routes in the domestic air transport market in South Africa.

\section{Conclusion}

Deregulation of the domestic aviation industry in South Africa introduced 'turbulent 'times for the sector. Of the new entrants to the industry only three have survived in a very competitive market: BA/Comair, kulula.com and Mango (the latter being state-owned). Deregulation has however brought significant benefits to the travelling public as, for the first time, airlines are now competing against each other, offering the travelling public a choice of airlines and fares, especially between the 'Golden Triangle' cities. It could also be argued that the low-cost revolution would not have taken place in a highly regulated market, as competition

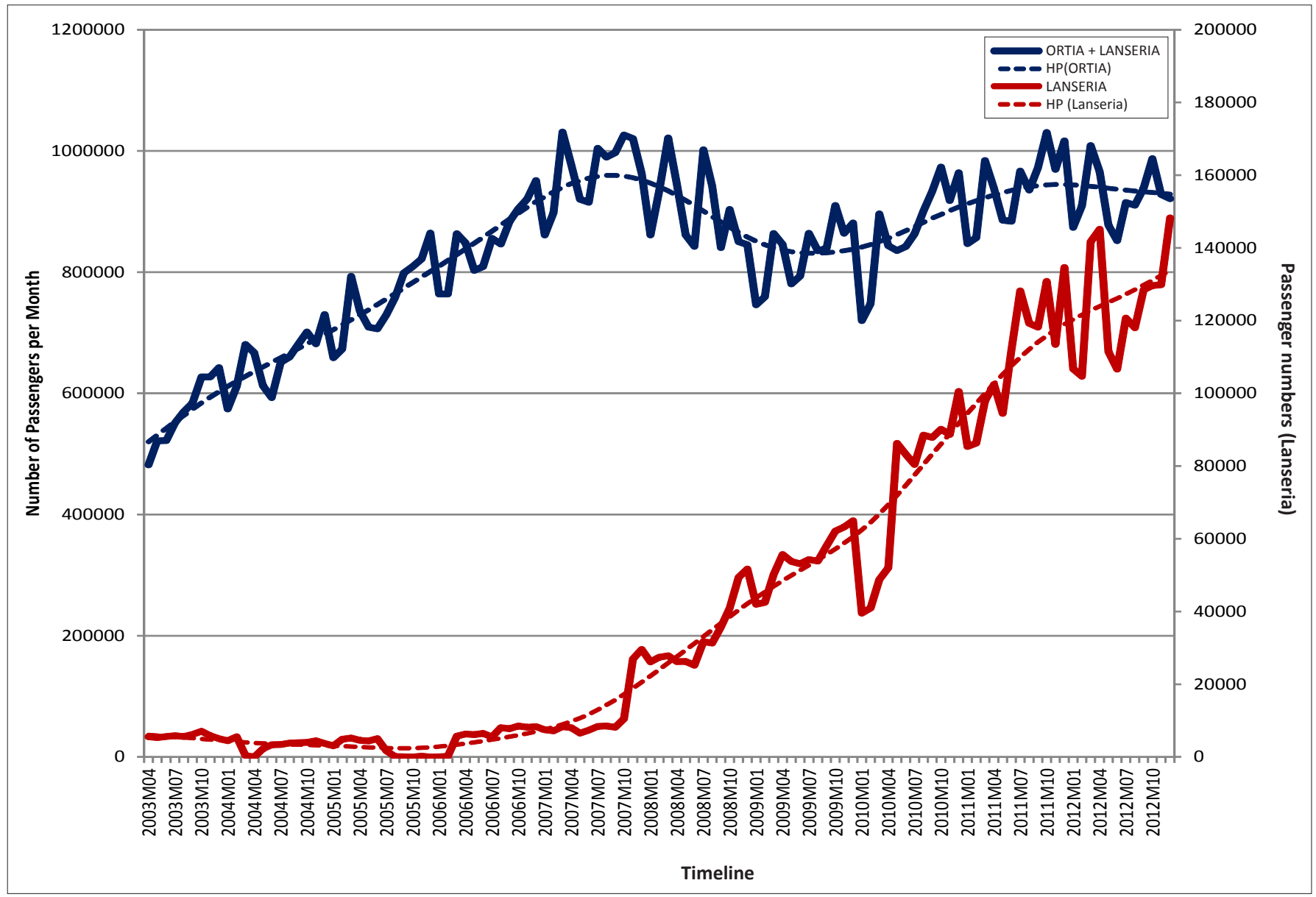

ORTIA + LANSERIA, Combined Oliver Reginald Tambo International Airport and Lanseria monthly passenger numbers; HP (ORTIA), Hodrick-Prescott filter for the Total Oliver Reginald Tambo International Airport and Lanseria passenger numbers; LANSERIA, Total Lanseria passenger numbers; HP (Lanseria), Hodrick-Prescott filter for Lanseria passenger numbers

FIGURE 5: Passenger trends at Oliver Reginald Tambo International and Lanseria International airports (total scheduled arrivals and departures). 
against SAA was not allowed prior to 1991. It would have been nearly impossible, as the legislation at the time placed onerous conditions on any applicant that wanted to compete against SAA on the main routes.

The purpose of this article was to describe the highlevel trends in the South African aviation industry since deregulation in 1991. The research indicates that the South African trends are, in general, in line with the deregulation or liberalisation experiences described in the US and Europe, where a number of developments characterise the aviation industry. One of the key features in these markets is the high level of new entrants to the airline markets, with a high number of these entrants failing to continue operations. This is true in the South African market, both in the 10 years immediately following deregulation, as well as in the period after 2001, which is characterised by the entry (and exit) of numerous low-cost carriers.

The entry and development of low-cost airlines and their subsequent growth in the market on the routes on which they operate is an international trend that is also significant in South Africa. Other global trends are: low-cost airlines achieving higher load factors than full-cost airlines; the subsequent response by the full-service airlines by increasing their own load factors; and the increasing use of secondary airports by the low-cost carriers. Trends in load factors are shown in Figure 3, which clearly depicts the increasing levels in load factors for the low-cost carriers, which is subsequently echoed by the increases in the full-service airlines' load factors.

The use of secondary airports is also reflected, but to a limited degree, as there is only one alternative airport on the 'Golden Triangle'. This is Lanseria, which serves as an alternative to ORTIA, in Johannesburg. In contrast to major trends in the US and Europe, all the SA low-cost airlines continue to serve the traditional main airports in Durban, Cape Town and Johannesburg. This is mainly due to the lack of alternative airports in Durban and Cape Town, as well as the prominence of ORTIA as a major aviation hub for domestic, regional and international air services. Most airlines therefore require at least a 'presence' at this airport in order to capitalise on its large passenger base.

Airline deregulation in SA has also resulted in traffic stimulation, mainly at the expense of the full-service airlines, as can be seen from Figure 1, which depicts the low-cost airlines' growing passenger market share. South Africa appears to be following world trends regarding low-cost airline market share. The current market share of about $40 \%-45 \%$ supports international trends on dense, short-haul routes.

Although full deregulation effects could not be measured, the analysis shows that the development of the low-cost carrier market has contributed significantly to air traffic growth in the country. It also shows increased asset utilisation throughout the industry, as illustrated by the increasing load factors for both the low-cost as well as the full-service airlines. Whilst the market still remains somewhat limited in scope, the analysis shows that the entrance of the low-cost carriers has contributed significantly to the restructuring of the market in South Africa, providing competition to the fullservice airlines, giving the South African travelling market choices and stimulating the market.

\section{Acknowledgements}

With special thanks to Dr Daniel Marais, ITLS (Africa) research associate, for assistance with data analysis.

\section{Competing interests}

The authors declare that they have no financial or personal relationship(s) that may have inappropriately influenced them in writing this article.

\section{Authors' contributions}

R.L. (University of Johannesburg) and J.W. (University of Johannesburg) were equally responsible for the interpretation of data and the writing of the article.

\section{References}

Abouelaziz, M., 2013, The impact of international air transport liberalisation - case of Moroccan Kingdom, viewed 09 August 2013, from http://icnwarsaw2013.org/ pre-icn/pre-icn-4b_Abouelaziz_-_Morocco_air_transport_liberalisation.pdf

Airports Company South Africa (ACSA), 2013, 'Passenger statistics', viewed 11 August 2013, from http://www.acsa.co.za/home.asp?pid=133

Africa News Service, 2000, 'British Airways acquires 18 percent shares in Comair', viewed 10 August 2013, from http://business.highbeam.com/3548/article1G1-59128624/british-airways-acquires-18-percent-shares-comair

Air Services Licensing, 1990, 'Act No. 115 of 1990', viewed 09 August 2013, from http://www.greengazette.co.za/acts/air-services-licensing-act_1990-115

Airlink, 2013, 'Airlink profile', viewed 10 August 2013, from http://www.flyairlink.com/ about_airlink.php

avjobs.com, n.d., 'Airline deregulation', viewed 07 August 2013, from http://www. avjobs.com/history/airline-deregulation.asp

Behrens, R. \& Wilkinson, P., 2001, 'South African urban passenger transport policy and planning practice, with specific reference to metropolitan Cape Town', viewed
10 August 2013, from http://www.cfts-uct.org/publication/south-african-urban10 August 2013, from http://www.cfts-uct.org/publication/south-african-urbanmetropolitan-cape-town/wppa_open/

Butcher, L., 2010, 'Aviation: European liberalisation, 1986-2002', viewed 08 August 2013, from www.parliament.uk/briefing-papers/SN00182.pdf

$\mathrm{CH}$-aviation, 2012, '1time finally suspends all operations and files for liquidation', viewed 01 August 2013, from http://www.ch-aviation.ch/portal/news/14302 1time-finally-suspends-all-operations-and-files-for-liquidation

Comair Limited, n.d., 'About us', viewed 10 August 2010, from http://www.comair. co.za/about-us

De Boer, E. \& Browning, R., 2013, 'The legacy effect', viewed 11 August 2013, from http://www.aimia.com/files/doc_downloads/AirlineLoyalty_LowCostCarriers.pdf

Department of Public Enterprises, 2007, 'SA Express', viewed 19 August 2013, from http://www.dpe.gov.za/state-7_saexpress

Department of Transport, 1990, The Domestic Air Transport Policy, Government Printers, Pretoria.

DiploNews, 2012, 'Brazil signs the Open Skies Agreement of the Latin American Civil Aviation Commission (LACAC)', viewed 21 February 2013, from http://www. diplonews.com/feeds/free/13_November_2012_343.php

Donzelli, M., 2010, 'The effect of low-cost air transportation on the local economy: Evidence from southern Italy', Journal of Air Transport Management 16(2), 121126. http://dx.doi.org/10.1016/j.jairtraman.2009.07.005

Economist.com, 2013, Flying cheap, viewed 11 August 2013, from http://www. economist.com/blogs/graphicdetail/2013/04/daily-chart-10

Flightglobal, 2002, 'Sun Air rises again in business class', viewed 10 August 2013 from http://www.flightglobal.com/news/articles/sun-air-rises-again-in-businessclass-143258/ 
Flightsite, 2012, 'Fly Mango Airlines', viewed 10 August 2013, from http://www. flightsite.co.za/flights/airlines/mango-airlines/

Flightsite, 2013, 'Kulula Airlines', viewed 10 August 2013, from http://www.flightsite. co.za/flights/airlines/kulula-airlines/

Fu, X., Oum, T.H. \& Zhang, A., 2010, 'Air transport liberalization and its impacts on airline competition and air passenger traffic', Transportation Journal 49(4), 24-41.

Gorman, L., 2009, 'What Happened to the Airline Industry viewed', 10 August 2013, from http://www.nber.org/digest/mar09/w14503.html

Gotravel24, 2013, 'Mango Flight Info', viewed 02 August 2013, from http://www.gotravel24.com/Flights/airlines/Mango

Graham, A. \& Dennis, N., 2010, 'The impact of low-cost airline operations to Malta', Journal of Air Transport Management 16(3), 127-136. http://dx.doi. org/10.1016/j.jairtraman.2009.07.006

ICAO Brazil, 2013, 'The liberalization of international air transportation in Brazil', viewed 09 August 2013, from http://www.icao.int/Meetings/atconf6/Documents/ WorkingPapers/ATConf.6.IP.013.2.en.pdf

ICAO Secretariat, 2008, 'Domestic market deregulation in South Africa', viewed 10 August 2013, from http://www.icao.int/sustainability/CaseStudies/StatesReplies/ SouthAfrica_En.pdf

Imara, 1998, 'Comair - Grant And Commencement Of Listing', viewed 10 August 2013 from https://trade.imara.co/free/sens/disp_news.phtml?tdate $=1998072208010$ $5 \&$ seq $=43 \&$ scheme $=$ imaraco

Inglada, V., Rey, B., Rodriguez-Alvarez, A. \& Coto-Millan, P., 2006, 'Liberalisation and efficiency in international air transport', Transportation Research Part A 40(1) 95-105. http://dx.doi.org/10.1016/j.tra.2005.04.006

International Air Services, 1949, Act No. 51 of 1949, viewed 09 August 2013, http:// www.greengazette.co.za/acts/air-services-act_1949-051

InterVISTAS, 2006, 'The economic impact of air service liberalization', viewed 14 July 2013, from http://www.intervistas.com/downloads/Economic_Impact_of_Air Service_Liberalization_Final_Report.pdf

Know India, n.d., 'Indian Aviation', viewed 28 July 2013, from http://www.knowindia. net/aviation.html

kulula.com, 2006, 'kulula.com extends network to include Lanseria Airport', viewed 10 August 2013, from http://www.kulula.com/press-room/archive/2006/3

Lanseria International Airport, 2012a, 'Launch of 1time flights from Lanseria International Airport', viewed 10 August 2013, from http://www.lanseria.co.za/ news/articles/2012/03/05/launch-of-1time-flights-from-lanseria-internationalairport

Lanseria International Airport, 2012b, '1time withdraws from Lanseria', viewed 10 August 2013, from http://www.lanseria.co.za/news/articles/2012/06/01/1timewithdraws-from-lanseria

Levine, M.E., 1987, 'Airline Competition in Deregulated Markets: Theory, Firm Strategy, and Public Policy', Yale Journal on Regulation 4(Spring), 393-494.

Lyth, P., 1997, 'Experiencing Turbulence', in J. McConville (ed.), Transport Regulation Matters, pp. 154-174, Transport Regulation Matters Pinter, London.
Moris, D., 2005, 'The High Price of Airline Deregulation', viewed 15 July 2013, from http://www.alternet.org/story/25495/the_high_price_of_airline_deregulation

Margo, C.S., 1984, Report of the Commission of Inquiry into Civil Aviation in South Africa: Book 1, Government Printer, Pretoria.

Najda, C., 2003, 'Low-Cost Carriers and Low Fares: Competition and Concentration in the U.S. Airline Industry', viewed 11 August 2013, from http://economics. stanford.edu/files/Theses/Theses_2003/Najda.pdf

Orlek, J., 2010, 'SAA speaks out on withdrawal from Durban-CT route', viewed 29 July 2013, from http://www.cargoinfo.co.za/WebsectionNews.aspx?Command=\&we bsectionno $=1 \&$ currentpage $=102 \&$ pagesize $=10 \&$ ccurrentpage $=1 \&$ cpagesize $=10 \&$ tabContent $\mathrm{No}=\&$ CAKeyDataNo $=0 \& \mathrm{News} N \mathrm{No}=11723$

Oum, T. H., Zhang, A. \& Fu, X., 2010, 'Air transport liberalization and its impacts on airline competition and air passenger traffic', viewed 01 August 2013, from http:// www.stl.polyu.edu.hk/Papers/IFSPA09-Papers/9_A013.pdf

Planespotters, 2013, '1time', viewed 10 August 2013, from http://www.planespotters net/search.php?q=1time

Poole Jr, R.W. \& Butler, V., 1998, 'Airline deregulation: The unfinished revolution', viewed 08 August 2013, from http://reason.org/files/2ad199e8224f814ae006d 35fbd9b2924.pdf

SA Express, 2013a, 'About us', viewed 10 August 2013, from http://www.flyexpress. aero/about-us/

SA Express, 2013b, 'Route network', viewed 10 August 2013, from http://www. flyexpress.aero/route-network/

Smethers, M., 2002, 'Air transport liberalisation in Europe', viewed 03 August 2013 from http://www.acac.org.ma/ar/Conference\%20Presentation/8.pdf

Smith, E., 1998, 'An evaluation of the impact of air transport deregulation in South Africa', viewed 28 May 2013, from https://ujdigispace.uj.ac.za/ handle/10210/6196

South Africa.To, 2012, 'Velvet Sky Airlines', viewed 12 August 2013, from http://www. southafrica.to/transport/Airlines/Velvet-Sky/Velvet-Sky.php

The Economist online, 2012, 'Top flights', viewed 11 Aug 2013, from http://www. economist.com/blogs/graphicdetail/2012/05/daily-chart-8

Spacelaw, n.d., 'Convention Relating to the Regulation of Aerial Navigation Signed at Paris, October 13,1919', viewed 09 August 2013, from http://www.spacelaw. olemiss.edu/library/aviation/IntAgr/multilateral/1919_Paris_conevention.pdf

The Wall Street Journal, 2013, 'Asia's Open Skies Are Clouded by Indonesia', viewed 21 February 2013, from http://online.wsj.com/article/SB1000142412788732380700 $4578284481581086720 . \mathrm{html}$

Travelstart, 2012, 'Cheap flights to Lanseria Airport', viewed 05 August 2013, from http://www.travelstart.co.za/lp/johannesburg/lanseria-flights

USLegal, n.d., 'Airline Deregulation Act law and legal definition', viewed 07 August 2013, from http://definitions.uslegal.com/a/airline-deregulation-act/

Wijaya, M., 2010, 'New heights for Asia's budget carriers', viewed 22 July 2013, from http://atimes.com/atimes/Southeast_Asia/LB17Ae01.html 